\title{
MODELING OF TEMPERATURE DISTRIBUTION IN BIOTISSUES
}

\author{
Teodora Petrova \\ Assoc. Prof. Ph.D., Faculty of Aviation, Vasil Levski National Military University, Dolna Mitropoliya, \\ District Pleven, Bulgaria, teodorapetrova33@abv.bg
}

\begin{abstract}
One of the widely used ways to model the spread of laser beams in biological tissues is through the Monte Carlo method. This article focuses on the distribution of temperature in human skin based on the results of the Monte Carlo method for a laser beam with a wavelength of $800 \mathrm{~nm}$. A mathematical model of the heat transfer process, based on the solution of the differential equations through the finite element method, was introduced. Simulations of the laser beam diffusion and the distribution of temperature in the skin were performed for two types of beams. The results of this work can be used to make an assessment of the energy levels of pulse laser treatment with different durations, during which a damage of biological tissue is observed, as well as to create standards for the safe use of laser systems.
\end{abstract}

Keywords: biological tissues, Monte-Carlo method, laser.

\section{INTRODUCTION}

There is a trend in modern biotechnology and physiology related to experimental and theoretical studies of heat transfer processes in the body as well as in its individual organs and tissues. Biological tissue is a specific physical environment with a complex structure and the study of heat transfer processes is essential.

The laws governing the laser beam penetration into tissues have a direct relation to the problem of the mechanism of biological impact of the laser beam. One of the reasons why the laser beam penetrates to a limited depth in tissues is because of the absorption of the beam and this is the initial link that precedes the sequence of changes that occur as a result of the organism being irradiated. The depth of the laser beam penetration into the biotissue is very important in practical terms, as it is one of the key factors for determining the possible limit of laser application.

Determining the mechanisms and the precise threshold characteristics of the field of ultrashort optical laser pulses in their effect on biological entities is of considerable importance for many practical and scientific applications in biotechnology and in medicine (Akhmanov, Vysloukh, Chirkin, 1988, 312 p.; Rulliere, 2005, 428 p.).

The mathematical modeling of the internal radiation of human biological tissues, based on the numerical solution of the thermal conduction equation, is of great practical significance (Antonov., Hristozov, 2017, pp. 310-325; Vesnin, Sedankin, 2012a, pp. 43-61; Vesnin, Kaplan, 2008b, pp. 82-87).

The work is aimed at solving the main problem of medicine, concerning the improvement of the efficiency of the methods for early treatment of oncological diseases (Losev, Mazepa, Zamechnik, 2014, p. 254). The 
conducted computational experiments will allow to investigate the influence of uncertainties in the spatial distribution of the physical parameters of biotissues on the temperature fields.

The work also examines the role of a complex small-scale structure in the formation of temperature distribution due to the strong spatial heterogeneity of the thermal conductivity of the various biological components. The transition from multilayer models to multicomponent biotissue, taking into account its structure and inhomogeneous parameters (thermal conductivity, water content, specific heat release, electrical conductivity, dielectric constant, thermal power) can improve the efficiency of thermal therapy of tumors at early stages (Jacques, 2011b, pp. 109-144).

The damage of biotissues is due to the temperature impact when laser optical radiation is absorbed, which leads to reversible or irreversible changes in its structure (Vogel, 2003, pp. 577-644; Wright, Barrett, Welch, 2002a). Irreversible damages can be divided into the following types, depending on the tissue temperature $\left(T_{\text {crit }}\right)$ : coagulation $T_{\text {crit }}=45-100^{\circ} \mathrm{C}$, vaporization $T_{\text {crit }} \geq 100^{\circ} \mathrm{C}$. At a temperature of $100^{\circ} \mathrm{C}$, the water molecules contained in most biotissues begin to evaporate. The large thermal vaporization of water is useful as far as it helps to remove excess heat and prevents overheating of adjacent tissues. If the water molecules evaporate and the laser effect continues, a further increase in tissue temperature will follow. After the water evaporates, the dehydrated tissues are very quickly heated to a temperature of $150^{\circ} \mathrm{C}$, which initiates the process of carbonization of the tissues (Müller, Sliney, 1989, p.253; Sliney, Trokel, 1993; Tuchin, 2016a, p. 030201; Welch, 2011a).

\section{DETERMINING THE DEPTH OF PENETRATION OF OPTICAL RADIATION BY USING THE MONTE-CARLO METHOD}

The numerical modulation of the diffusion of laser radiation with wavelength of $800 \mathrm{~nm}$ in biotissues, using the Monte-Carlo method (Jacques, 2011b, pp. 109-144; Meglinski, Doronin, 2012) allows us to obtain data on the intensity distribution in the penetration depth.

In the matemathical modeling, the Henyey-Greenstein function is accepted as the scattering phase function:

$$
p(\theta)=\frac{1-g^{2}}{\left(1+g^{2}-2 g \cos \theta\right)^{3 / 2}},
$$

where $p(\theta)$ is a probability function, $\theta$ is a scattering angle, $g$ is the average cosine of the scattering angle. For the $\theta$ angle we obtain:

$$
\theta=\arccos \left(\frac{1+g^{2}-\left(\frac{1-g^{2}}{1+g^{2}-2 g R}\right)^{2}}{2 g}\right),
$$

where $R$ is a random evenly distributed number in the interval $(0,1)$.

The experiment was performed with a beam with a Gaussian distribution of $0,1 \mathrm{~cm}$ and focused Gaussian beam with a pulse duration of $500 \mathrm{~ns}$ and wavelength of $800 \mathrm{~nm}$, refractive index $n=1,4$ and mean cosine of the scattering angle $g$. Optical parameters of human tissues are measured in in vitro conditions and are presented in Table 1 (Tuchin, Utz, Yaroslavsky, 1994, pp. 3178-3188; Tuchin, Utz, Yaroslavsky, 1993a, pp. 234-258).

Table 1. Optical parameters of biotissues

\begin{tabular}{|c|c|c|c|c|}
\hline Biotissue & $\lambda, \mathrm{nm}$ & $\mu_{a}, \mathrm{~cm}^{-1}$ & $\mu_{s}, \mathrm{~cm}^{-1}$ & $g$ \\
\hline Dermis & 800 & 1,7 & 175 & 0,85 \\
\hline
\end{tabular}

Figure 1 shows the results from the Monte-Carlo simulated photon distribution in the dermis for a beam with Gaussian distribution and radius of $5 \times 10^{-3} \mathrm{~cm}$ and a focused Gaussian beam with the same radius according to the penetration depth (on the $z$ axis) and the radius of remoteness from the $z$ axis. 

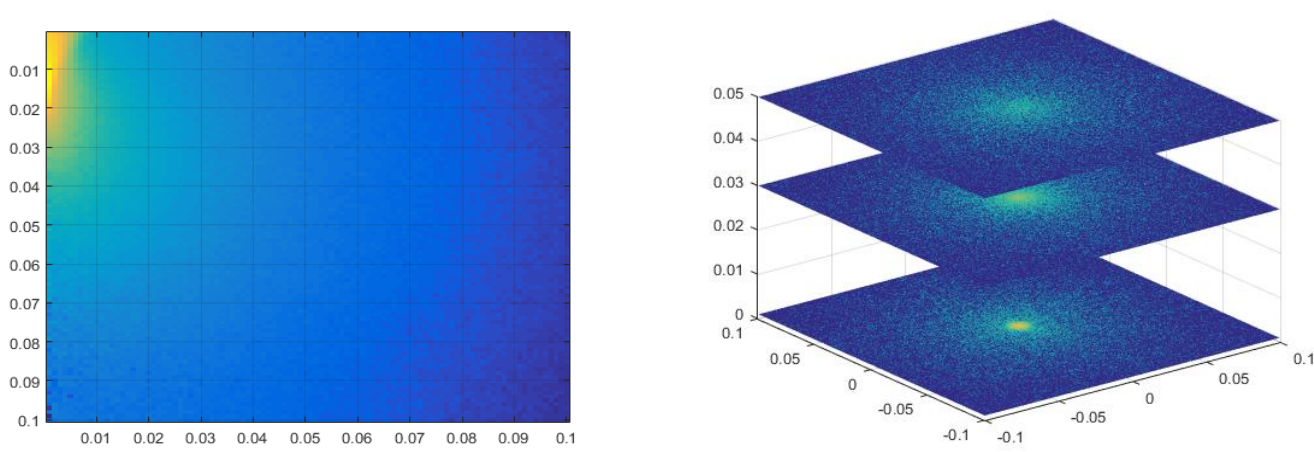

a)
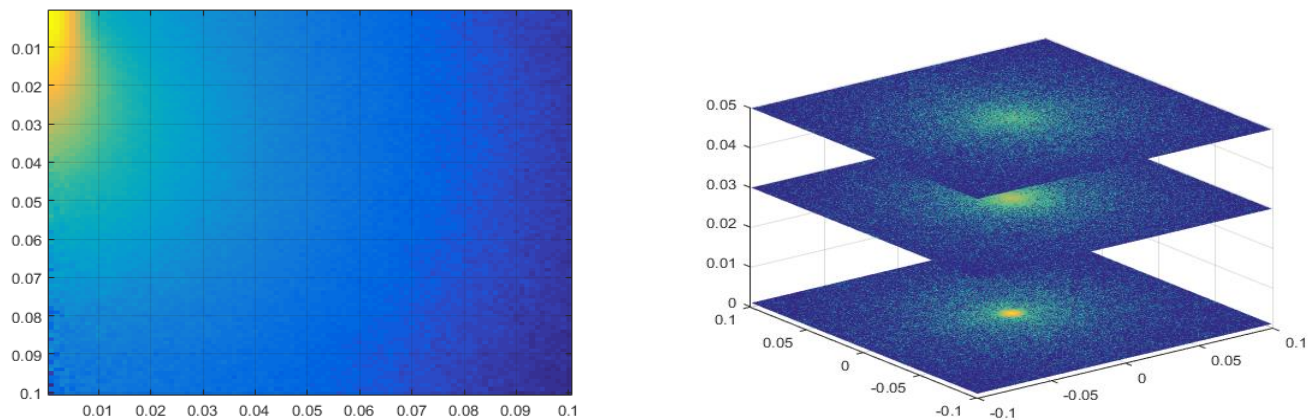

b)

Figure 1. Density distribution of the photon transfer in dermis of: a) a focused Gaussian beam and b) a beam with a Gaussian distribution.

The obtained results show that the scattering of a focussed Gaussian beam in the dermis is less than the scattering of a beam with Gaussian distribution. Figure 1a clearly illustrates that the beam initially focuses upon penetration in the dermis and then remains with a relatively constant width that is smaller than that of the non-focussed beam at the same depth of penetration (Figure 1 b). At depths greater than $0.035 \mathrm{~cm}$, both beams diminish considerably, as this is more pronounced for the focused beam.

The nature of the interaction of laser radiation with biological tissues depends on the absorption coefficient for a particular wavelength. The examined modified Monte Carlo method has several advantages. This method is applicable to environments with different geometries and it produces three-dimensional information about the beam diffusion in tissue. When emitting 1 million photons, the error of the method does not exceed $1 \%$ of the value obtained.

\section{MODELING OF HEAT PROCESSES}

When biotissues aborb laser radiation, heat is generated. The modeling should be solving the problem for optimization of the laser emitter parameters and should evaluate the results obtained from the laser effect of the already selected laser on the biological environment. The generated heat causes a number of effects, which correspond to different power levels that are used, and leads to tissue heating within the physiological temperature, which in turn leads to reversible or irreversible changes in the state of the tissues. The generated heat, described as a source of heat $S$ at point $\mathbf{r}$, which is proportional to the fluence rate of light $\varphi(\mathbf{r})\left(\mathrm{mW} / \mathrm{cm}^{2}\right)$ and absorption coefficient $\mu_{a}(\mathbf{r})$ at this point:

$S(\mathbf{r})=\mu_{a}(\mathbf{r}) \varphi(\mathbf{r})$.

The bioheat equation is written based on the energy balance in the system and describes the temporary change in biotissue temperature at a given point in space $\mathbf{r}$, in the absence of blood flow in the tissue:

$\rho c \frac{\partial T(\mathbf{r}, t)}{\partial t}=\nabla\left[k_{m} \nabla T(\mathbf{r}, t)\right]+S(\mathbf{r})$

where $\rho$ is the tissue density, $c$ is the tissue-specific heat, $T(\mathbf{r}, t)$ is the tissue temperature at time $t, k_{m}$ is 
the coefficient of thermal conductivity, $S(\mathbf{r})$ term that describes the heat source which determines the speed of heat release at point $\mathbf{r}$.

In this equation certain things, such as convection, reflection, vaporization, metabolic heat effects are not taken into consideration as they are negligible in many practical cases. It is assumed that the source term is constant over the time interval of heating. The first term, to the right of the equal sign, describes the heat conduction (usually from point $\mathbf{r}$ ), and the source term accounts heat generation at the expense of photon absorption. Initial and boundary conditions must be taken into account in order to solve this equation. The initial conditions are the tissue temperature at moment of time $t=0$, and the boundary conditions depend on the tissue structure and the geometry of laser heating (Friedman, 2011a, pp. 1189-1198).

Figure 2 shows the results of the modeling of temperature distribution in tissues during the implementation of the bioheat equation (2) on the basis of the energy balance in the system, the solution being obtained by applying the finite element method. The study was performed for the biological structure of the dermis. The data used for the dermis is shown in Table 2 (Tuchin, Utz, Yaroslavsky, 1994, pp. 3178-3188; Tuchin, Utz, Yaroslavsky, 1993a, pp. 234-258).

\section{Table 2. Biological structure of the dermis}

\begin{tabular}{|c|c|c|c|}
\hline Biotissue & $\rho,\left[\mathrm{kg} / \mathrm{m}^{3}\right]$ & $c,[\mathrm{~J} / \mathrm{kg} \cdot \mathrm{K}]$ & $k,[\mathrm{~W} / \mathrm{m} \cdot \mathrm{K}]$ \\
\hline Dermis & 1200 & 3800 & 0,53 \\
\hline
\end{tabular}

Figure 2 shows the temperature distribution, as focused Gaussian beam and a beam with Gaussian distribution were investigated at the same duration of impact of the beam.
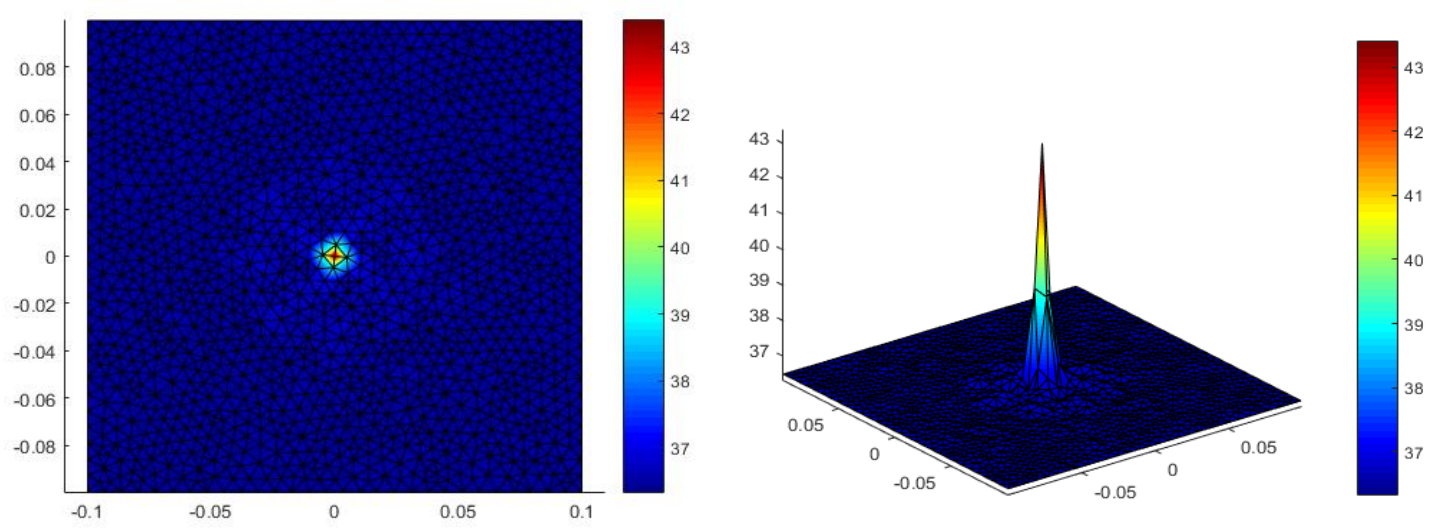

a)
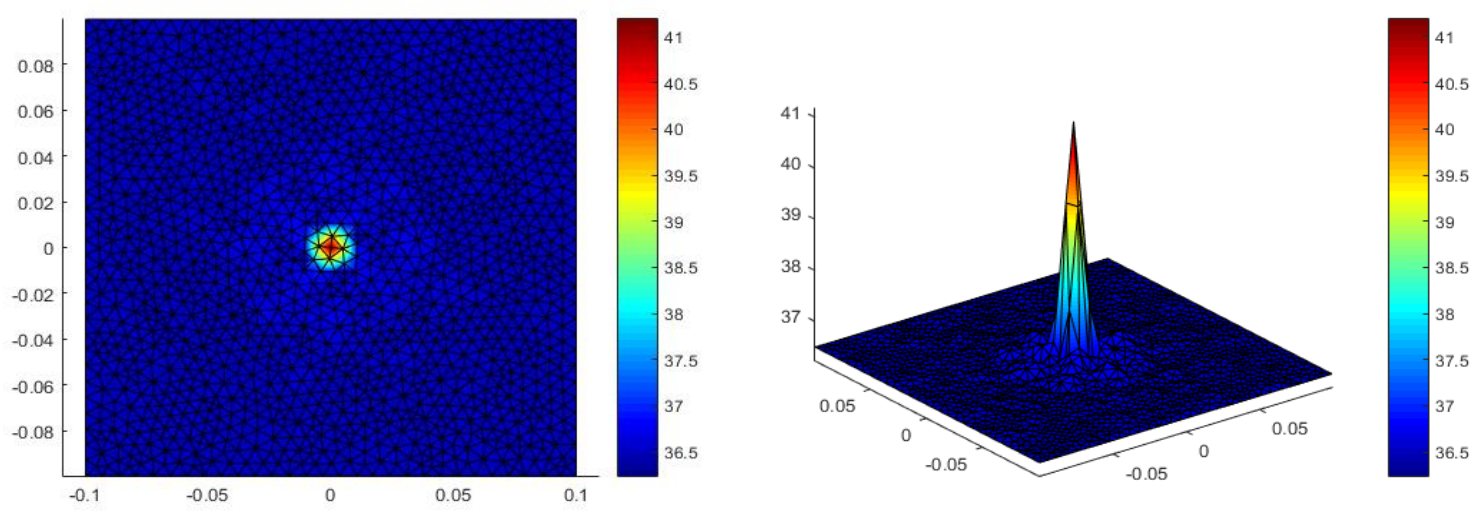

b)

Figure 2. Temperature distribution (a-b).

From Figure $2 a$, it can be observed that the focussed Gaussian beam heats the tissue to a temperature of $43^{\circ} \mathrm{C}$. And Figure $2 b$ shows a distribution of a beam with Gaussian destribution temperature at which the 
tissue temperature reaches $41^{\circ} \mathrm{C}$. The figure shows that the Gaussian beam temperature distribution covers a larger area of the section to which the beam has reached, compared to the focused beam. This indicates that the use of a focused beam is more efficient and allows for more precise heating of only the desired part of the tissue.

\section{DISCUSSION}

The morphological diversity of tissues determines the different nature of light passing through them. The size of the cells, of the cellular structural elements and of the connective biotissues is within the range from a few tens of centimeters to hundreds of micrometers (Bagratashvili, Sobol, Shechter, 2006; Saratov, 2000; Tuchina, 2007; Tuchin, 2011). It should be noted that when laser radiation is applied to the skin, damage to the biological tissues occurs, which cannot be explained by the standard thermalmelting mechanism (Fredriksson, 2008a). The difference is explained by the multiphoton excitation of electrons, which occurs at a time equal to the duration of the pulse when the energy is transferred directly to the atomic subsystem (Dyukin, Martsinovskiï, Shandybina, Yakovlev, Nikiforov, Guk, 2011, pp. 558-562; Stampfli, 1990, pp. 71637173). In this case, the water molecules serve as a transmission link which absorbs energy from the laser radiation and excites the vibrational modes of collagen with a relaxation time of about 3 ps. (Kropman, Bakker, 2001, pp. 2118-2120; Kropman, Nienhuys, Bakker, 2002, p. 077601). At various temperature ranges, the biological tissue can undergo different chemical and structural changes. At $T=40 \div 45^{\circ} \mathrm{C}$ irreversible damage to the tissues is not to be expected (enzymes may be activated and changes in the membrane or cell death may occur only with sufficiently long heating). Heating of tissues to a temperature of $42 \div 45^{\circ} \mathrm{C}$ degrees in medical practice is used for local thermotherapy (Parvanov, Sotirov, Sakakushev, 2006a, Sakakushev, Sotirov, Parvanov, 2006b; Sotirov, Sakakushev, Koriykov, Georgiev, Zhel, Popesku, 2010; Sotirov, Sakakushev, Tonev, Georgiev, 2006c; Sotirov, Ivanov, Sakakushev, 2016b; Parvanov, Sakakushev, Sotirov, 2014a; Sakakushev, Sotirov, Parvanov, Angelov, 2014b).

\section{CONCLUSIONS}

The wavelength and the laser radiation power are determined by the size of the tumor and the absorption spectrum of the pathological tissue. All types of laser thermotherapy require careful determination of the laser radiation dosimetry, reliable data on the optical and thermophysical parameters of the biotissues and the use of the means to control these parameters. The developed mathematical model describes the heat transfer processes based on an analytical solution of a system of equations describing the dynamics of the electron and atomic subsystems, the results of the experiment showing that the scattering of a focused Gaussian beam in the dermis is less than that of a beam with Gaussian distribution. It can clearly be seen how the beam initially focuses upon penetration in the dermis and then remains with a relatively constant width that is smaller than that of the non-focussed beam at the same depth of penetration. At depths greater than $0.035 \mathrm{~cm}$, both beams diminish considerably, and this is more pronounced for the focused beam. The beam with Gaussian distribution covers a larger area of the section to which the beam has reached compared to the focused beam. This indicates that the use of a focused beam is more efficient and allows for more precise heating of the desired part of the tissue (Petrova, 2016; Petrova, Petrov, 2018, pp.213-228; Petrova, Petrov, 2014a, pp. 201-206; Tuchin, 2007a).

\section{REFERENCE LIST}

Akhmanov S.A., Vysloukh V.A., Chirkin A.S. (1988). Optics of Femtosecond Laser Pulses. Moscow, Nauka Publ., 1988, 312 p. (In Russian).

Antonov S. I., Hristozov I. S. (2017). Models of the existing system for maintenance and repair of the arrangement, Collection of papers: "Defense And Security, Arms, Technologies, Logistics Communication And Computing Technologies, Social Science", "Vasil Levski" National Military University-Artillery, Air Defense and CIS Faculty, Shumen, Bulgaria, 2017, pp. 310-325, ISSN 23677902.

Bagratashvili V.N., Sobol E.N., Shechter A. B.M. (2006). Laser engineering of cartilage, Fizmatlit, 2006.

Dyukin R.V., Martsinovskiǐ G.A., Shandybina G.D., Yakovlev E.B., Nikiforov I.D., Guk I.V. (2011). Dynamics of the permittivity of a semiconductor acted on by a femtosecond laser. Journal of Optical Technology, 2011 , vol. 78 , no. 8, pp. 558-562. 
Rulliere Ed. C. (2005). Femtosecond Laser Pulses: Principles and Experiments. 2nd ed. Springer, 2005, 428 p.

Friedman N.J. et al. (2011a). Femtosecond laser capsulotomy. Journal of Cataract \& Refractive Surgery, 2011, vol. 37, no. 7, pp. 1189-1198. doi: 10.1016/j.jcrs.2011.04.022.

Fredriksson I., Larsson M., Stromberg T. (2008a). Optical microcirculatory skin model: assessed by Monte Carlo simulations paired with in vivo laser Doppler flowmetry. Journal of Biomedical Optics, 2008, vol. 13, no. 1, art. 014015. doi: 10.1117/1.2854691.

Jacques S. (2011b). Monte Carlo modeling of light transport in tissue (steady state and time of flight). In: Optical-Thermal Response of Laser-Irradiated Tissue. Springer, 2011, pp. 109-144. doi: 10.1007/978-90-481-8831-4_5.

Kropman M.F., Bakker H.J. (2001). Dynamics of water molecules in aqueous solvation shells. Science, 2001, vol. 291, no. 5511, pp. 2118-2120. doi: 10.1126/science.1058190.

Kropman M.F., Nienhuys H.K., Bakker H.J. (2002). Real-time measurement of the orientational dynamics of aqueous solvation shells in bulk liquid water. Physical Review Letters, 2002, vol. 88, no. 7, pp. 077601. doi: 10.1103/physrevlett.88.077601.

Losev A.G., Mazepa E.A., Zamechnik T.V. (2014). About several typical traits in the diagnosis of mammary glands pathologyaccrding to the date of microwave radiometry//Modern problems of science and education, 2014. № 6, p. 254.

Meglinski I., Doronin A.V. (2012). Monte Carlo modeling for the needs of biophotonics and biomedical optics. Advanced Biophotonics: Tissue Optical Sectioning/Eds. V.V. Tuchin, R.K. Wang. Taylor \& Francis, 2012.

Müller G.J., Sliney D.H. (1989). Dosimetry of Laser Radiation in Medicine and Biology. SPIE Press, Bellingham, 1989, $253 \mathrm{p}$.

Petrova T., (2016). Modelling the impact of lasers on bio-tissues, LAMBERDT Academic Publishing, 2016, ISBN: 978-3-659-89346-9.

Petrova T., Petrov Zh., (2018). Modelling the Distribution of Lasers in Biological Tissues, Int J Bioautomation, 22 (3), 213-228, doi: 10.7546/ijba.2018.22.3.213-228.

Petrova T., Petrov Zh. (2014a). Specifics of temperature distribution at multilayer medium under the influence of laser radiation, Tenth Anniversary Scientific Conference with International Participation SPACE, ECOLOGY, SAFETY, Sofia 2014, pp. 201-206, ISSN 1313 - 3888.

Sliney D.H., Trokel S.L. (1993). Medical Lasers and their Safe Use. NY, Academic Press, 1993.

Stampfli P., Bennemann K.H. (1990), Theory for the instability of the diamond structure of $\mathrm{Si}$, Ge, and C induced by a dense electronhole plasma. Physical Review B, 1990, vol. 42, no. 11, pp. 7163-7173. doi: 10.1103 physrevb.42.7163.

Saratov, (2000), Fall Meeting, Optical Technologies in Biophysics and Medicine/Ed. by Tuchin V.V., Zimnyakov D.A., Pravdin A. B. Proc. SPIE. 2000. V. 4001.

Tuchin V.V. (2016a). Tissue optics and photonics: light-tissue interaction II. Journal of Biomedical Photonics \& Engineering, 2016, vol. 2, no. 3, p. 030201. doi: 10.18287/jbpe16.02.030201.

Tuchin V.V., Utz S.R., Yaroslavsky I.V. (1994). Tissue optics, light distribution, and spectroscopy//Opt. Eng. 1994. V. 33. P. 3178-3188.

Tuchin V.V., Utz S.R., Yaroslavsky I.V. (1993a) Skin optics: modeling of light transport and measuring of optical parameters//Medical optical tomography: functional imaging and monitoring/Eds. G.Muller, B. Chance, R.Alfano et al. Bellingham: SPIE, 1993. V. IS11. P. 234-258.

Tuchina V.V. (2007). Optical biomedical diagnostics. T.1, 2 / Per. from English M., Fizmatlit, 2007; Handbook on Optical Biomedical Diagnostics. V. PM107 / Ed. by Tuchin V.V. Bellingham, SPIE Press, 2002.

Tuchin V.V. (2007a). Optics of biological tissues: light scattering methods in medical diagnostics/Transl. from English M .Fizmatlit, 2011; Tuchin V.V. Tissue Optics: Light Scattering Methods and Instruments for Medical Diagnosis. Second edition. Bellingham, WA: SPIE Press, 2007. V. PM 166.

Vesnin S.G., Sedankin M.K. (2012a), Development of a series of antenna applicators for non-invasive measurement of the temperature of human body tissues at different//Engineering magazine: science 
and innovations, 2012. - № 11. P. 43-61.

Vesnin S.G., Kaplan M.A., Avakjan R.S. (2008b). Modern microwave radiometry of the mammary glands // Medetsinsky almanac, 2008, № 3. pp. 82-87.

Vogel A., Venugopalan V. (2003). Mechanisms of pulsed laser ablation of biological tissues. Chemical Reviews, 2003, vol. 103, pp. 577-644. doi: 10.1021/cr010379n.

Wright C.H.G., Barrett S.F., Welch A.J. (2002a). Laser-tissue interaction. In: Lasers in Medicine, D.R. Vij, K. Mahesh (eds.). Boston, Dordrecht, London, Kluwer Academic Publishers, 2002.

Welch A.J., Van Gemert M.J.C. (2011a). Optical-Thermal Response of Laser-Irradiated Tissue. NY, Springer, 2011. doi: 10.1007/978-90-481-8831-4.

Parvanov, S., Sotirov, B., Sakakushev, B. (2006a). Prilozheniya na vizualnoto otsenyavane na mashinostroitelni izdeliya. // Nauchni trudove na Rusenski universitet „A. Kanchev”, tom 45, 2006, broy seriya 2.1, str. 104 - 109, ISSN 1311 - 3322 (Първанов, С., Сотиров, Б., Сакакушев, Б. Приложения на визуалното оценяване на машиностроителни изделия. // Научни трудове на Русенски университет „А. Кънчев”, том 45, 2006, брой серия 2.1, стр. 104 - 109, ISSN 1311 3322).

Sakakushev, B., Sotirov, B., Parvanov, S. (2006b). Organoleptichno otsenyavane na tochni otvori s malak diametar i golyama dalzhina. // XVI Nauchen simpozium s mezhdunarodno uchastie „Metrologiya i metrologichno osiguryavane 2006", Sozopol, 2006, broy 16, str. 211 - 215, ISSN 954 - 33

(Сакакушев, Б., Сотиров, Б., Първанов, С. Органолептично оценяване на точни отвори с малък диаметър и голяма дължина. // XVI Научен симпозиум с международно участие „Метрология и метрологично осигуряване 2006”, Созопол, 2006, брой 16, стр. 211 - 215, ISSN 954 - 33).

Sotirov, B., Sakakushev, B., Koriykov, Ts., Georgiev, Ts, Zhel, Zh. F, Popesku, G. (2010). «Menidzhmant na kachestvoto i metrologiya» - spetsialnost ot evropeyskoto obrazovatelno prostranstvo. // Standartizatsiya, Metrologiya, Sertifikatsiya, 2010, broy I, str. 25-28, ISSN 1310-0831 (Сотиров, Б., Сакакушев, Б., Корийков, Ц., Георгиев, Ц, Жел, Ж. Ф, Попеску, Г. «Мениджмънт на качеството и метрология» - специалност от европейското образователно пространство. // Стандартизация, Метрология, Сертификация, 2010, брой I, стр. 25-28, ISSN 1310-0831).

Sotirov, B., Sakakushev, B., Tonev, D., Georgiev, Ts. (2006c). Za obuchenieto po metrologiya za inzheneri. // Standartizatsiya, Metrologiya, Sertifikatsiya, 2006, broy 12, str. 25-29, ISSN 1310-0831 (Сотиров, Б., Сакакушев, Б., Тонев, Д., Георгиев, Ц. За обучението по метрология за инженери. // Стандартизация, Метрология, Сертификация, 2006, брой 12, стр. 25-29, ISSN 1310-0831).

Sotirov, B., S., Ivanov, B., Sakakushev. (2016b). Izsledvane na kompleksen metod na izmervane, osnovan na klasicheskata dvuprofilna proverka na tsilindrichni zabni kolela s pravi zabi. // KNOWLEDGE International journal scientific papers, 2016, broy Vol 13.1, str. 355-356, ISSN ISSN $1857-92$ (Сотиров, Б., С., Иванов, Б. Сакакушев. Изследване на комплексен метод на измерване, основан на класическата двупрофилна проверка на цилиндрични зъбни колела с прави зъби. // KNOWLEDGE International journal scientific papers, 2016, брой Vol 13.1, стр. 355-356, ISSN ISSN 1857-92).

Parvanov, S., Sakakushev, B., Sotirov, B. (2014a). Eksperimentalno izsledvane na organoleptichno izmervane na visoki temperaturi.. V: XXIV Natsionalen nauchen simpozium s mezhdunarodno uchastie "Metrologiya i metrologichno osiguryavane 2014", Sozopol, Sofiya, 2014, str. 530-533, ISBN 1313-9126 (Първанов, С., Сакакушев, Б., Сотиров, Б.. Експериментално изследване на органолептично измерване на високи температури.. B: XXIV Национален научен симпозиум с международно участие “Метрология и метрологично осигуряване 2014”, Созопол, София, 2014, стр. 530-533, ISBN 1313-9126).

Sakakushev, B., Sotirov, B., Parvanov, S., Angelov, Yu. (2014b). Vazmozhnosti i perspektivi za organoleptichno otsenyavane na visoki temperaturi v oblastta na tehnikata. // Nauchni trudove na rusenskiya universitet - 2014, tom 53, seriya 2, ruse, izdatelski tsentar pri Rusenski universitet „Angel Kanchev“, 2014, str. 115-119, ISBN 1311-3321 (Сакакушев, Б., Сотиров, Б., Първанов, С., Ангелов, Ю. Възможности и перспективи за органолептично оценяване на високи температури в областта на техниката. // Научни трудове на русенския университет - 2014, том 53, серия 2, русе, издателски център при Русенски университет „Ангел Кънчев“, 2014, стр. 115-119, ISBN 1311-3321). 